\title{
Effectiveness of Health Education Diabetic Foot Care with Leaflet and Audiovisual Media Toward Knowledge
}

\author{
Yusuf Efendi \\ Indonesia \\ Email: \\ epd.yusuf@yahoo.co.id
}

Received : March 12, 2019

Accepted : October 13, 2019

Published : November 26, 2019

\begin{abstract}
Diabetic foot care is a foot treatment performed on diabetics to prevent ulcers (sores). The steps that must be done are, check the blood sugar levels regularly, wash your feet with warm water, check for injuries to the feet, do nail care and use footwear. Audio visual media is one of the media of counseling that attracts and stimulates more senses than media leaflets. This study aims to determine the effectiveness of audio visual media and leaflets on improving knowledge of foot care knowledge in people with diabetes mellitus. This research is a type of Pre Experimental research with the design of one group pretest and postest. The study was conducted by dividing respondents into 2 groups classified as 1) groups given health education through media leaflets and 2) groups given health education through Audiovisual media. The population of this study amounted to 106 people with a sample of 102 people, each of 52 samples in each health center determined by purposive sampling based on inclusion and exclusion criteria. The analysis used is the Wilcoxon Sign Range Test and Mann-Whitney test analysis. The results showed that Leaflet and Audiovisual media were able to provide an increase in changes in the level of knowledge ( $p=0.032$ and 0.017$)$ after counseling. So this study proves the use of audio visual media is more effective for health education activities in improving knowledge of Deabetic foot care.
\end{abstract}

Keywords: Diabetic Foot Care, Audio Visual Media, Leaflet Media, Knowledge 


\section{INTRODUCTION}

In the current era of globalization, the health sector has experienced many developments and developments in the sciences that steal the attention of the public. With the existence of these problems, the health status of the community has also experienced a decline or disturbance. At present the health status has become a necessity to be maintained for every member of the community who lives in a certain area, of course, requires the role of health workers in improving the health status of the community, because the current health status has been considered valuable and has to be improved by each individual. Health education is a combination of learning experiences planned based on sound theory that provides individuals, groups, and communities to obtain information and skills needed to make quality health decisions (Linda, et al. 2017)

Providing information through health education is a very important requirement in the field of health, the development of information technology that is very helpful in providing information to every individual in need is one of the biggest challenges facing nursing today. The role of nurses as educators in providing health education must be truly competent (Puskar, Aubrecht, Beamer and carozza, 2004) (In the book Niman, S. 2017)

Effective health education is supported by the use of media that is attractive and more easily accepted by the target. One of the media that can be used is audio visual media. The use of audiovisuals involves all the sensory devices of learning, so that the more sensory tools involved in receiving and processing information, the more likely the contents of the information can be understood and maintained in memory (Notoatmodjo, 2012).

The success of the health education program which includes health behavior and the health domain has a very big role in realizing quality human resources and must be supported by all parties, especially the community. This program aims to improve public health and certainly make them aware of the importance of health itself. According to the latest International Diabetes Federation (IDF) data in 2014, around 387 million of the world's population suffer from DM and it is estimated that by 2035 this number will increase to 592 million. Indonesia is the country that ranks 7 th in the world with 8.5 million people with diabetes mellitus (IDF, 2015) while East Java province is in the top 10 prevalence of DM patients in Indonesia (6.8 million). Whereas in Bojonegoro, the prevalence of DM in 2016 was 27,875 (DINKES Bojonegoro 2016).

The importance of knowledge and skills that must be possessed by people with diabetes mellitus can help nurses in carrying out education and counseling. Health education for people with diabetes mellitus has an important role to change behavior by increasing the patient's understanding of the disease in order to achieve optimal health and adjusting psychological conditions and a better quality of life. Health education in patients with diabetes mellitus is also needed because the management of diabetes mellitus requires special lifelong handling behaviors. Patients not only learn skills for caring for themselves to avoid sudden fluctuations in blood glucose levels, but also 3 must have preventive behavior in lifestyle to avoid long-term diabetic complications (maghfuri, 2016).

There are two complications of diabetes mellitus, including acute complications and chronic complications. Acute complications occur due to acute imbalance of blood glucose levels, namely: hypoglycemia, diabetic ketoacidosis and hyperosmolar non ketosis hyperglycemia (maghfuri, 2016).

Chronic complications consist of makroangiopati (constriction of large blood vessels) such as peripheral, coronary, cerebrovascular and vascular heart disease, mikroangiopati (narrowing of capillary arteries) if it occurs in the retina of the eye causing diabetic retinopathy and in the kidneys causing diabetic nephropathy, diabetic neuropathy affects all types nerves, namely peripheral, autonomic and spinal nerves. Neuropathy complications cause problems in the form of diabetic foot ulcers. The mechanisms for diabetic foot ulcers include: a result of noncompliance in taking preventive measures, examining the feet, lacking medical treatment, inappropriate patient activities, being overweight, using inappropriate footwear, lack of health education and foot care (PERKENI, 2 015).

One prevention effort in patients with diabetes mellitus with complications of diabetic neuropathy is foot care. Foot care is a daily activity of patients with diabetes mellitus which consists of checking the condition of the feet every day, keeping feet clean, cutting nails well, choosing the right footwear, prevention of foot injuries, and early management of foot injuries. Good foot care can prevent and reduce diabetic foot complications by up to 50\% (ADA, 2012)

In this study, researchers conducted interviews with 10 respondents. The results obtained at the interview were 9 people who said they had never received health education about foot care and 1 person 
received health education about foot care after being exposed to an ulcer. From these results, Diabetes Mellitus sufferers say they have never received health education about diabetic foot care properly and they say that foot care is known after the patient has foot injuries. In connection with that the writer is interested in researching about "Effectiveness of Health Education Diabetic Foot Care with Leaflet and Audiovisual Media on Knowledge in Cotton Health Center and Dander Bojonegoro Health Center"

\section{MATERIALS AND METHODS}

The research design that will be used in this study is to use a pre-experimental design with a twogroup pretest-posttest design. One group of subjects was observed before the intervention (pretest), then observed again after the intervention (posttest).

\section{RESULT}

1. Frequency distribution based on Pre health education test Diabetic Foot Care with Leaflet Media on Knowledge of Foot Care in Diabetes Mellitus Patients in Bojonegoro Kapas Health Center

Tabel 1 Frequency distribution based on Pre health education test Diabetic Foot Care with Leaflet Media on Knowledge of Foot Care in Diabetes Mellitus Patients in Bojonegoro Kapas Health Center

\begin{tabular}{ccc}
\hline Knowledge & Frequency & Percent $(\%)$ \\
\hline Good & 8 & 15,4 \\
\hline Enaugh & 26 & 50,0 \\
\hline Less & 18 & 34,6 \\
\hline Total & 52 & 100,0
\end{tabular}

Based on table 1, it shows that out of 52 respondents after the Pre Test was conducted, some respondents in the Kapas Health Center had as many as 26 respondents (50.0\%) knowledge about diabetic foot care.

2. Frequency distribution based on health education Test Post Diabetic Foot Care with Leaflet Media on Knowledge of Foot Care in Diabetes Mellitus Patients in Bojonegoro Kapas Health Center

Tabel 2 Frequency distribution based on health education Test Post Diabetic Foot Care with Leaflet Media on Knowledge of Foot Care in Diabetes Mellitus Patients in Bojonegoro Kapas Health Center

\begin{tabular}{ccc}
\hline Knowledge & Frequency & Percent (\%) \\
\hline Good & 11 & 21,2 \\
\hline Enaugh & 32 & 61,5 \\
\hline Less & 9 & 17,3 \\
\hline Total & 52 & 100,0 \\
\hline
\end{tabular}

Based on table 2, it shows that out of 52 respondents after more than half of respondents in the Kapas Health Center conducted a Test Post, 32 respondents (61.5\%) had enough knowledge about diabetic foot care.

3. Frequency distribution based on pre diabetic foot care health education test with audiovisual media on foot care knowledge in people with diabetes mellitus in Bojonegoro cotton health center

Tabel 3 Frequency distribution based on pre diabetic foot care health education test with audiovisual media on foot care knowledge in people with diabetes mellitus in Bojonegoro cotton health cente 


\begin{tabular}{ccc}
\hline Knowledge & Frequency & Percent $(\%)$ \\
\hline Good & 3 & 5,8 \\
\hline Enaugh & 46 & 88,5 \\
\hline Less & 3 & 5,8 \\
\hline Total & 52 & 100,0 \\
\hline
\end{tabular}

Based on table 3 it shows that out of 52 respondents after the Pre Test, some respondents in the Dander Public Health Center had enough knowledge about diabetic foot care as many as 46 respondents $(88.5 \%)$.

4. Frequency distribution based on health education diabetic foot test post with audiovisual media on foot care knowledge in people with diabetes mellitus in Bojonegoro cotton health center

Tabel 4 Frequency distribution based on health education diabetic foot test post with audiovisual media on foot care knowledge in people with diabetes mellitus in Bojonegoro cotton health center

\begin{tabular}{ccc}
\hline Knowledge & Frequency & Percent (\%) \\
\hline Good & 32 & 61,5 \\
\hline Enaugh & 17 & 32,7 \\
\hline Less & 3 & 5,8 \\
\hline Total & 52 & 100,0 \\
\hline
\end{tabular}

Based on table 4 it shows that out of 52 respondents after doing Post Test more than a portion of respondents in the Dander Public Health Center had 32 respondents $(61.5 \%)$ had good knowledge of diabetic foot care.

5. Statistical Test Results of Diabetic Foot Care Health with Leaflet Media on Knowledge of Foot Care in Diabetes Mellitus Patients at Bojonegoro Kapas Health Center using the wicoxon statistical test as follows

Tabel 5 Statistical Test Results of Diabetic Foot Care Health with Leaflet Media on Knowledge of Foot Care in Diabetes Mellitus Patients at Bojonegoro Kapas Health Center using the wicoxon statistical test as follows

\begin{tabular}{lr}
\hline \multicolumn{2}{c}{ Test Statistics $^{\mathbf{b}}$} \\
\hline pos_test_leaflet - pre_test_leaflet & \\
\hline$Z$ & \\
\hline Asymp. Sig. (2-tailed) & $-3,207^{\text {a }}$ \\
\hline
\end{tabular}

Based on table 5 shows that the results of statistical tests conducted with Wilcoxon to 52 respondents using a 0.05 degree of error and the results obtained $p$ value of 0.001 . If the value of $p$ value <degree of error, the hypothesis is accepted.

6. Statistical Tests on Health Education of Diabetic Foot Care with Audiovisal Media on Knowledge of Foot Care in Diabetes Mellitus Patients in Dander Bojonegoro Health Center using the wicoxon statistical test as follows

Tabel 6 Statistical Tests on Health Education of Diabetic Foot Care with Audiovisal Media on Knowledge of Foot Care in Diabetes Mellitus Patients in Dander Bojonegoro Health Center using the wicoxon statistical test as follows 
Test Statistics ${ }^{\mathrm{b}}$

post_test_audiovisual - pre_test_audiovisual

\begin{tabular}{lr}
\hline$Z$ & $-5,385^{\mathrm{a}}$ \\
\hline Asymp. Sig. (2-tailed) &, 000
\end{tabular}

Based on table 6 shows that the results of statistical tests conducted with Wilcoxon to 52 respondents using a 0.05 degree error and the results of $p$ value of 0,000 are obtained. If the value of $p$ value $<$ degree of error, the hypothesis is accepted.

7. Statistical Tests on Health Education of Diabetic Foot Care with Leaflet and Audiovisal Media on Knowledge of Foot Care in Diabetes Mellitus Patients in Dander Bojonegoro Health Center using the Man Whitney statistical test as follows:

Tabel 7 Statistical Tests on Health Education of Diabetic Foot Care with Leaflet and Audiovisal Media on Knowledge of Foot Care in Diabetes Mellitus Patients in Dander Bojonegoro Health Center using the Man Whitney statistical test as follows:

\begin{tabular}{lcc}
\hline & \multicolumn{2}{c}{ Test Statistics $^{\mathbf{b}}$} \\
\hline & pos_test_leaflet & post_test_audiovisual \\
\hline Mann-Whitney U &, 007 &, 001 \\
\hline Wilcoxon W &, 032 &, 029 \\
\hline Z & 2,621 & 2,321 \\
\hline Asymp. Sig. (2-tailed) &, 032 &, 017 \\
\hline Exact Sig. [2*(1-tailed &, $006^{\text {a }}$ &, $002^{\text {a }}$ \\
Sig.)] & & \\
\hline
\end{tabular}

\section{DISCUSSION}

Health Education of Diabetic Foot Care with Leaflet Media on Knowledge of Foot Care in Diabetes Mellitus Patients in Bojonegoro Kapas Health Center

The results of this study indicate that out of 52 respondents after being given diabetic foot care health education with leaflet media more than half of the respondents in the Kapas Health Center had sufficient knowledge of diabetic foot care as many as 32 respondents $(61.5 \%)$

Diabetic foot care is foot care performed in diabetics to prevent ulcers (sores). The steps that must be taken, namely, checking blood sugar levels regularly, washing feet with warm water, checking for injuries to the feet, doing nail care and using footwear (Brunnert \& Suddart, 2014)

Health education is an important picture and part of the role of professional nurses in the efforts of health education and disease prevention (preventive) that have been carried out since the days of Florence Nightingale in 1959. (Nursalam, 2013)

Health education about diabetic foot care done at the Kapas Health Center also uses media. The media used in leaflet media, leaflet media containing information about diabetic foot care were packaged with writing designs, images and attractive colors. Leaflet media has several advantages including interesting to see, easy to understand, more concise in delivering information content, stimulating imagination in understanding leaflet content and can be read by a wider audience. Besides having the advantage of leaflet media, it also has several disadvantages, among others, if the design is wrong, the leaflet will not be interesting to read, leaflet media can also lead to boredom and perception that may differ from what the researcher wants, this is because the respondent cannot ask questions things that are not understood contained in leaflets and leaflet media are also easily lost. Another form of weakness is that the printed media leaflets require more expensive fees. Health education using leaflet media is one form of learning for the elderly so they must continue to carry out health education activities so that the knowledge formed can be reflected in actions taken by the elderly. One form of attention and acceptance from respondents can be seen from their willingness to respond to research also during the process of health education, the respondents showed a good attitude, namely paying attention to what was conveyed by the communicator seriously, the attention was drawn from the results 
of SPSS with the Wolcoxon Test using a 0.05 degree of error and the result of $p$ value was 0.001 . For the increase in knowledge it is not possible only with the stimulus without the process of attention and acceptance that exists in the elderly DM sufferers themselves. With the presence of self-awareness causes DM sufferers want and are able to prevent the tifak to get injured (ulcer).

\section{Health Education for Diabetic Foot Care with Audiovisual Media on Knowledge of Foot Care in Diabetes Mellitus Patients in Dander Bojonegoro Health Center}

The results of this study indicate that out of 52 respondents after being given diabetic foot care health education with audiovisual media more than half of the respondents in the Dander Health Center had 32 good knowledge of good diabetic foot care $(61.5 \%)$.

The results showed that the average value of knowledge before health education with video media compared with the average value of knowledge after health education with video media experienced changes, it can be concluded that there is effectiveness of health education with video media on changes in knowledge levels compared to levels knowledge before being given health education with video media and after being given health education with video media obtained a value of $p<0.017$. The use of video is very good to be used to help improve knowledge, especially to emphasize the material that is very important to be known by respondents, besides this video media will facilitate researchers in conveying information, facilitating understanding of concepts and absorption of elderly people with DM, also helping researchers to present material in a directed and interesting manner so that the research objectives can be achieved. Elderly people with DM also become concentrated and understand more quickly because in addition to researchers explain respondents can see something abstract that can be seen through video. One effort to improve the knowledge of elderly people with DM about diabetic foot care is in the form of health education with video media, with the right media promotion is a strategic step in an effort to increase the awareness of elderly DM sufferers to prevent ulcers. . This is based on the idea that elderly people with DM can share their knowledge with family, friends and the surrounding environment. In the end this elderly person will become a health agent who will socialize to many people, so this promotion is not only for themselves, but will be useful for others.

In respondents at the Dander Health Center health education with video media extension officers provided material on diabetic foot care with the help of video media and respondents listened or listened carefully and orderly. Video media can improve knowledge because respondents get the new experience they get in the video, especially about diabetic foot care, because the video media relies on the hearing and vision of the target, where the use of audiovisuals involves all sensory devices, so that more sensory tools are involved in receiving and processing information the more likely the contents of the information can be understood and maintained in memory effectively moving images and sound effects can facilitate the goal of understanding the contents of information so that it can increase knowledge

Increased attitude (affective) in the positive direction can be done by creating feelings of pleasure in things - things that are learned. Therefore to support the change of knowledge towards a positive implementation of health education is made as attractive as possible by carrying out activities that are not monotonous during counseling. The atmosphere, counseling with video media is more interesting to the elderly of DM patients because they are entertained with the images and sounds produced by video and video media can also display an event that looks more real so the elderly do not not feel bored. Knowledge is influenced by exposure to mass media or information. By providing information about diabetic foot care, knowledge is obtained that will affect one's attitude. After being given health education about diabetic foot care, the knowledge of DM patients about diabetic foot care increased. This happens because DM patients have received stimulus in the form of information about diabetic foot care. Puskesmas is an ideal place to provide information and education about diabetic foot care. This activity is important because the continuous provision of information about diabetic foot care can increase the awareness and understanding of the elderly in a good way of diabetic foot care. Providing information in the form of film screenings turned out to be able to increase knowledge which would later make elderly people with DM practice foot care in their daily lives. 


\section{Effectiveness of Diabetic Foot Care Health Education with Leaflet and Audiovisual Media on Knowledge of Foot Care in Diabetes Mellitus Patients in Dander Health Center and Kapas Bojonegoro Health Center}

From the results of this study indicate that there are differences in the effectiveness of diabetic foot care health education with leaflet and audiovisual media on foot care knowledge in people with diabetes mellitus in dander health center and bojonegoro cotton health center, this is seen from the Mann-Whittney difference test results obtained $p$ value of 0.032 with Leaflet media and the results obtained $p$ value of 0.017 with audiovisual media using a 0.05 degree of error

The increase in knowledge of respondents in Dander Health Center was better than the increase in respondents' knowledge in Cotton Puskesmas because respondents in Dander Health Center were provided with audiovisual health education with LCD, so many respondents were more interested and concerned about visualization and description of diabetic foot care, so memories were stronger, more easily understood and gives a good impression. The use of video media is more effectively applied to DM patients as a health education media compared to lefleate media. This is because health education with video media can lead to a tendency for DM patients to enjoy the storyline in the video so that it is easy to capture the messages implied in the story on the video. The video presentation contains ways of diabetic foot care, so that respondents understand the video more so that the information delivered is more easily accepted and understood, while the lefleat media contains information on how to treat diabetic foot packaged formally more monotonically, especially if the leaflets distributed are not wellwritten and uninteresting images and images.

Media leaflets and video media is one means that can be used to clarify a material where the two media have their respective strengths and weaknesses in stimulating the senses of the respondent, where the advantages and disadvantages of leaflet media are used as discussion material, the packaging contains images and writing, if needed it can be reprinted, it can be stored so that it can be read over and over again, while the disadvantages are that it can cause boredom and different perceptions, if the design is wrong then the leaflets will not be interesting to read, expensive printing costs. The advantages and disadvantages of video media are messages that are delivered quickly and easily remembered, there are images and sounds, can be used for small and large groups, very good for explaining a process / skill, while the shortcomings are difficult to revise if something goes wrong, relatively expensive, when the image is displayed the image will continue so that not everyone can understand the message being conveyed, the available video is not always in accordance with the desired learning needs. In this case it can be seen that respondents who have been treated with health education with video media have an average value of change of knowledge better than respondents who have been given counseling with leaflet media, not that the leaflet media is not good for the learning process but the media leaflets can be used as a companion from other media.

Health education about diabetic foot care provided with leaflets and video media can provide a pleasant atmosphere for people with DM. Activities carried out in a pleasant atmosphere allow the growth of a positive attitude so that when receiving material DM patients are not bored and in the end are expected to be able to understand the material. Seeing the results of research conducted on DM patients at Kapas Health Center and Dander that with the help of print media (leaflets) and electronic media (videos) were able to increase knowledge and be able to change DM patients' perceptions of diabetic foot care, this means that there has been a positive impact on DM patients

\section{CONCLUSION}

From the results of this research show that there is a difference in the effectiveness of health education of diabetic foot care with leaflets and audio-visual media toward knowledge foot care in diabetics mellitus in dander and kapas bojonegoro, it is seen from a different test results Mann-Whittney retrieved the value of the $p$ value of 0.032 with leaflets and media obtained the result value of the $p$ value of 0.017 with audiovisual media using error 0.05 degrees.

\section{REFERENCES}

ADA. (2012). American Diabetes Asosiation Diagnosis And Classification Of Diabetes Mellitus. Diabetes Care.

Brunnert \& Suddart. (2014). Buku Ajar Keperawatan Medikal Bedah. Edisi 12. Jakarta : EGC 
Dinas Kesehatan Bojonegoro. (2016). Profil Kesehatan Kabupaten Bojonegoro 2016.

International Diabetes Federation (IDF). 2015. Diabetes Evidence Demands Real Action From The UN Summit On Non-Communicable Disease.

Linda, Dkk. 2017. Promosi kesehatan dan pendidikan kesehatan. Malang : MNC

Maghfuri Ali. (2016). Buku Pintar Perawatan Luka Diabetes Mellitus. Jakarta : Salemba Medika

Niman, Susanti. 2017. Promosi dan pendidikan kesehatan, Jakarta: Transinfo Media

Notoatmodjo. (2012). Promosi kesehatan dan perilaku kesehatan. Jakarta : Rineka Cipta

Nursalam. (2013). Pendidikan dalam keperawatan. Jakarta. Salemba Medika.

PERKENI. (2015). Perkumpulan Endokrinologi Indonesia. Konsensus Pengelolaan Dan Pencegahan Diabetes Melitus Tipe 2 Di Indonesia 2015. 